\title{
Evaluation of Fetal Autopsy Findings in the Hatay Region: 274 Cases
}

\author{
Hatay Yöresinde Fetal Otopsi Bulgularının Değerlendirilmesi: \\ 274 Olgu
}

\author{
Sibel HAKVERDiं ${ }^{1}$, İsmail GÜZELMANSUR ${ }^{2}$, Arif GÜNGÖREN ${ }^{3}$, Serhat TOPRAK ${ }^{1}$, Mehmet YALDIZ ${ }^{1}$, \\ Ali Ulvi HAKVERDi²
}

Departments of ${ }^{1}$ Pathology and ${ }^{3}$ Obstetrics and Gynecology, Mustafa Kemal University, Faculty of Medicine, ANTAKYA/HATAY, TURKEY

${ }^{2}$ Department of Radiology, Antakya Mozayik Obstetric and Pediatric Hospital, ANTAKYA/HATAY, TURKEY

\begin{abstract}
Objective: The aim of this study was to present the incidence of fetal anomalies in our region of Hatay, Turkey in order to determine the efficiency of prenatal diagnosis through fetal autopsy, and to compare our statistical data with other national and international studies.

Material and Method: This study was conducted on 274 fetuses from terminated pregnancies due to abnormal prenatal findings and intrauterine deaths from 2005 to September 2010. Fetuses were evaluated through postmortem examination, external measurements, $\mathrm{X}$-rays, Magnetic Resonance Images, Multislice Computerized Tomography and photographs. The autopsy was completed by the histological examination of each organ.
\end{abstract}

Results: Autopsy was conducted on 274 fetuses. A fetal anomaly was detected in 160 (58.39\%) cases. The central nervous system contained the most frequent structural defects (79 cases, $49.38 \%$ ), followed by malformations in the musculoskeletal system in 36 cases $(22.5 \%)$. The most frequent multiple system anomalies were central nervous system defect and bilateral adrenal agenesis, musculoskeletal system malformations and urinary system defects. Fetal autopsy provided additional findings in 43 cases $(26.88 \%)$.

Conclusion: Fetal autopsy is a very important procedure and an integral part of the general prenatal management. New findings through this method may suggest invaluable data for parents about potential risks in future pregnancies.

Key Words: Autopsy, Fetal diseases, Prenatal diagnosis, Hatay

\section{ÖZ}

Amaç: Bölgemizdeki fetal anomali insidansını belirlemek, ülkemizdeki ve diğer ülkelerdeki istatistiksel verileri karşılaştırmak, fetal otopsi aracılığı ile prenatal tanının doğruluğunu belirlemek.

Gereç ve Yöntem: 2005-2010 yılları arasında anormal prenatal bulgular veya intrauterin ölüm nedeni ile sonlandırılmış 274 olgu çalışmaya alındı. Fetuslar postmortem değerlendirildi. Dış vücut ölçümleri alındı, röntgen, manyetik rezonans, bilgisayarlı tomografi ve fotoğrafları çekildi. Otopsi organların histolojik incelemesi yapilarak tamamland.

Bulgular: Toplam 274 olguya otopsi yapildı. 160 olguda $(\% 58,39)$ fetal anomali saptandı. Santral sinir sistemi anomalileri en sık yapısal defektti (79 olgu, \%49,38). Bunu kas iskelet sistemi anomalileri izledi (36 olgu, \%22,50). Çoklu sistem tutulumunda santral sinir sistemi anomalilerine bilateral adrenal agenezi ve kas iskelet sistemi anomalilerine de üriner sistem defektleri eşlik etmekteydi. Toplam 43 olguda $(\% 26,88)$ otopsi sonucunda ek anomali saptandı.

Sonuç: Fetal otopsi çok önemli bir işlemdir ve genel prenatal değerlendirmenin ayrılmaz bir parçasıdır. Bu yöntemle elde edilen yeni bulgular ebeveynlere gelecek gebeliklerdeki muhtemel riskler için çok önemli bilgiler verebilir.

Anahtar Sözcükler: Otopsi, Fetal hastalıklar, Prenatal tanı, Hatay

The prenatal diagnosis based on ultrasound scan findings may not be adequate for the parents to make the decision of pregnancy termination. Therefore, clinicians, geneticists, pediatric surgeons, radiologists and pathologists are required to be consulted for certain diagnosis of anomalies as well as the application of right methods so as to overcome such cases (1).

Correspondence: Sibel HAKVERDí

Department of Pathology, Mustafa Kemal University, Faculty of Medicine, ANTAKYA/HATAY, TURKEY

E-mail: hakverdisibel@yahoo.com Phone: +90 3262291000 
A further issue to be dealt with thoroughly is the implications of anomalies in fetuses for future pregnancies. Women will normally want to know whether their future pregnancies will end in similar anomalies in their fetuses, and so the exact data obtained from autopsy examination can be offered to them. A specialist pediatric pathologist might provide important information about the possible risk of recurrence $(2,3)$.

The autopsy is quite significant in giving complementary information (4). We therefore always recommend at our center that an autopsy should be performed on almost all fetuses ranging from pregnancies terminated due to fetal anomalies to intrauterine fetal death.

The aim of this study was to present the distribution of fetal anomalies in our region of Hatay province, to determine the efficiency of postnatal diagnosis through fetal autopsy, to compare our statistical data with other studies, and to evaluate the need to employ advanced screening methods for higher precision in diagnosis.

\section{MATERIAL and METHODS}

All terminated pregnancies from 12 to 40 weeks due to abnormal prenatal findings, and intrauterine fetal deaths (IUFD) from 2005 to September 2010 at Mustafa Kemal University, Medical Faculty, Gynecological and Obstetric Clinic-Hatay (a total of 274 fetuses) were evaluated prospectively. Among these fetuses, 115 with abnormal prenatal findings were referred to the high risk pregnancy clinic from prenatal outpatient clinics of our hospital for further investigation and 159 of them were directly received as intrauterine dead fetuses. After obstetric and ultrasonographic evaluation of these cases' family histories, detailed patient history and examinations of other affected family members were carried out.

The families were informed about the technique of fetal physical examination by the obstetrician and were asked whether they wanted this evaluation or not. After termination of pregnancy, all of the fetuses were referred to our department for autopsy with the written consent of the patients as regards the analysis procedures. Autopsy was conducted on all the fetuses in our clinic: anthropometrical measurements including height, weight, head circumference, hand, middle finger, foot length, chest, and arm span were taken and all fetuses were photographed.

All cases were X-rayed in order to detect some specific localised skeletal defects. Karyotype analysis was done in all 45 cases with an undiagnosed multiple malformation. Amniocentesis (35 cases) and fetal cord blood samples (10 ca- ses) after termination were also used for chromosomal evaluation. Furthermore, multislice computerized tomography (MSCT), a more advanced method of screening, was used in 12 cases with skeletal dysplasia. We also used MSCT in a congenital cervical neuroblastoma case to view the degree of invasion of the tumour into the bone and cerebral tissues. In 2 sacrococcygeal teratoma cases, we obtained magnetic resonance images (MRI) to see the depth of invasion of the tumor into soft tissues.

All the fetuses were carefully examined, their photographs and radiographs were taken and the results were recorded on the computer. The autopsy was completed by the histological examination of each organ, including the umbilical cord in all of the cases, and the placenta in 20 fetuses by the Department of Pathology. On the other hand, patients rejected autopsy because of moral and religious reasons for 41 fetuses and we examined the fetus, took photographs and radiographs and recorded the findings.

\section{RESULTS}

The annual average birth rate in Hatay Province is 29.583 and these two hospitals handle an average of 9.000 of these cases (32.40\%) (5). Two hundred and seventy-four consecutive fetuses were examined during the five-year study period from January 2005 to September 2010. Among these fetuses, 115 were from women whose pregnancy had been terminated medically for prenatally detected fetal abnormalities and 159 were dead in utero. Of these, autopsy was performed in 233 (85\%) cases. A fetal anomaly was detected in 160 (58.39\%) cases. Among the fetuses with no fetal anomaly, 49 were detected to have autolysis, 12 hydrops fetalis, and 2 adrenal gland and liver calcification. Among the dead fetuses, 47 cases were found to have no pathology (Table I). Forty-one families rejected the autopsy. In twenty cases there were central nervous system anomalies such as anencephaly, spina bifida etc. Ten cases showed musculoskeletal system malformation. No gross pathological finding was identified in the rest.

As regards the causes of fetal anomalies, we focused on some other aspects related to couples, such as the consanguinity, regional factors and family history, which might yield clues about genetic transmission probabilities. In $44(27.5 \%)$ cases, the couples were married to their cousins, which showed consanguinity.

Among the cases with anomalies, $60(37.5 \%)$ were female, $90(56.25 \%)$ were male, and the sex of 10 cases (6.25\%) could not be detected. In 1 case, the fetus was diagnosed to have Piepkorn syndrome (short ribs, short neck, wideset eyes, narrow and short ribcage), and one year later 
the second fetus from the second pregnancy of the same mother had the same pathology. In the other case, we found gastroschisis, encephalocele, and micrognathia. Two years later, the fetus from the second pregnancy of the mother was found to have gastroschisis and musculoskeletal anomaly. In both cases, the women were informed about the possible risks in their future pregnancies and the second pregnancies with anomalies would therefore be ended in the earlier stages of pregnancy

Neural tube defect and other defects in the central nervous system were the most frequent structural defects, accounting for $79(49.38 \%)$ of the cases. These were, in turn, followed by malformations in the musculoskeletal system in $36(22.5 \%)$, and in genital organs and the urinary system in $19(11.86 \%)$ cases. The final detailed diagnoses based on autopsy and cytogenetics are listed in Table II and summarized with photographs in Figures 1A-D, 2A-D.

Routine karyotype analysis was not offered in cases of neural tube defects. Chromosomal abnormalities accounted for 11 $(24.44 \%)$ of the 45 cases. This includes trisomy 21, trisomy

18 , trisomy 13 and $2 \mathrm{q}$ deletion syndrome. Down's syndrome was the most common finding in this group (8).

In cases multiple system anomalies, the most frequent one was central nervous system defect and bilateral adrenal agenesis, followed by musculoskeletal system malformations and urinary system defects (renal dysplasia, polycystic kidney).

Table I: Fetal autopsy findings (274 cases)

\begin{tabular}{|l|c|c|}
\hline Type of Pathology & Number of cases & \% \\
\hline Fetal Anomaly & 160 & 58.39 \\
\hline Hydrops Fetalis & 12 & 4.37 \\
\hline $\begin{array}{l}\text { Adrenal Gland \& Liver } \\
\text { Calcification }\end{array}$ & 2 & 0.72 \\
\hline Acute Chorioamnionitis & 4 & 1.45 \\
\hline Autolysis & 49 & 17.88 \\
\hline No Specific Pathology & 47 & 17.15 \\
\hline Total & 274 & 100 \\
\hline
\end{tabular}

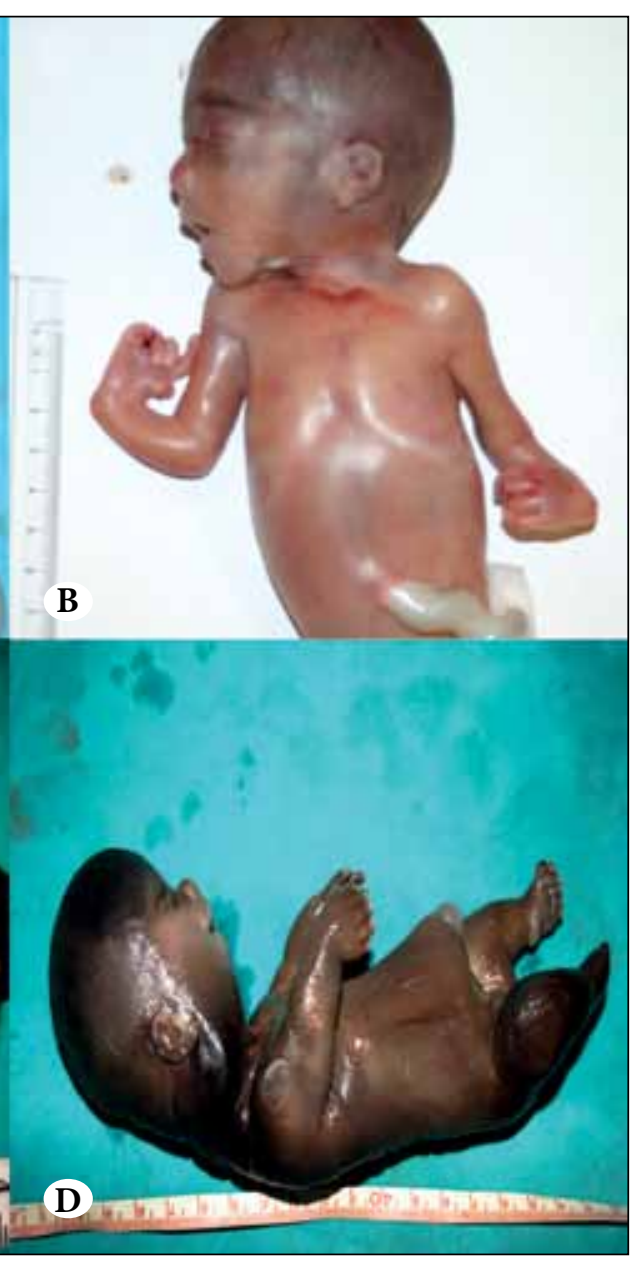

Figure 1: A) Fetal Anencephaly, B) Radial Ray Malformation, C) Piepkorn Syndrome, D) Thanatophoric Dwarfism. 
In 12 cases, an umbilical cord and placenta pathology were present: 3 cases of chorangiosis and 9 cases of single umbilical artery $(7.5 \%)$.

A congenital tumor was detected in 7 (4.38\%) cases, 5 of which were sacrococcygeal teratoma, 1 congenital facial hemangioma and 1 congenital cervical neuroblastoma.
In the fetuses examined after prenatal diagnosis of malformations, the ultrasound findings in 156 cases but four were confirmed by fetal autopsy. In the ultrasonographic examination, three of these four cases were found to have intrauterine growth retardation, oligohydramnios/ anhydramnios and abnormality (cystic change) in the

Table II: Final diagnoses based on autopsy

\begin{tabular}{|c|c|}
\hline Diagnoses & n (\%) \\
\hline $\begin{array}{l}\text { Congenital malformations of the nervous } \\
\text { system }\end{array}$ & $79(48.7)$ \\
\hline Anencephaly & 33 \\
\hline Isolated hydrocephaly & 9 \\
\hline Occipital encephalocele & 5 \\
\hline Occipital meningocele & 2 \\
\hline Spina bifida & 7 \\
\hline Spina bifida with anencephaly & 9 \\
\hline Iniencephaly & 5 \\
\hline Acrania & 2 \\
\hline Holoprosencephaly & 2 \\
\hline Aprosencephaly & 1 \\
\hline Dandy-Walker malformation & 1 \\
\hline Arnold-Chiari malformation & 1 \\
\hline Microcephaly & 2 \\
\hline $\begin{array}{l}\text { Congenital malformations of the } \\
\text { musculoskeletal system }\end{array}$ & $36(22.5)$ \\
\hline Achondrogenesis & 2 \\
\hline Thanatophoric dwarfism & 6 \\
\hline Osteogenesis imperfecta & 4 \\
\hline Piepkorn syndrome & 2 \\
\hline Verles-David-Pfier-Hirschfelder & \\
\hline Rott syndrome & 1 \\
\hline Radial Ray Malformation & 2 \\
\hline Artrogryposis Akinezi Sequence & 3 \\
\hline Body Stalk Anomaly & 1 \\
\hline Severe phacomelia & 1 \\
\hline Polidactyly & 4 \\
\hline Syndactyly & 2 \\
\hline Absence of monodactyly & 1 \\
\hline Unspecified & 7 \\
\hline $\begin{array}{l}\text { Congenital malformations of genital organs } \\
\text { and the urinary system }\end{array}$ & $19(11.86)$ \\
\hline Bilateral renal agenesis & 7 \\
\hline Unilateral renal agenesis & 3 \\
\hline Infantile polycystic kidney disease & 4 \\
\hline Bilateral multicystic renal displasia & 5 \\
\hline $\begin{array}{l}\text { Congenital malformations of the } \\
\text { gastrointestinal system }\end{array}$ & $15(9.38)$ \\
\hline Gastroschisis & 11 \\
\hline Omphalocele & 3 \\
\hline Anal atresia & 1 \\
\hline
\end{tabular}

\begin{tabular}{|c|c|}
\hline Diagnoses & n (\%) \\
\hline Complex anomalies/defined syndrome & $12(7.5)$ \\
\hline $\begin{array}{l}\text { Lethal Short Limb Dwarfism } \\
\text { (Dysmorphic Face) } \\
\text { Lethal multiple pterygium syndrome } \\
\text { Prune Belly Syndrome } \\
\text { Meckel Gruber Syndrome } \\
\text { Jacho-Levin Syndrome } \\
\text { Joubert Syndrome } \\
\text { Central Pentalogy } \\
\text { Fetal Face Syndrome }\end{array}$ & $\begin{array}{l}1 \\
1 \\
1 \\
4 \\
1 \\
1 \\
2 \\
1\end{array}$ \\
\hline Congenital placental malformations & $12(7.5)$ \\
\hline $\begin{array}{l}\text { Single umbilical artery } \\
\text { Chorangiosis }\end{array}$ & $\begin{array}{l}9 \\
3\end{array}$ \\
\hline Chromosomal anomalies & $11(6.8)$ \\
\hline $\begin{array}{l}\text { Down Syndrome } \\
\text { Trisomy } 13 \\
\text { Trisomy } 18 \\
\text { 2q Deletion Syndrome }\end{array}$ & $\begin{array}{l}8 \\
1 \\
1 \\
1\end{array}$ \\
\hline Tumor & $7(4.38)$ \\
\hline $\begin{array}{l}\text { Sacrococcygeal teratoma } \\
\text { Facial Hemangioma } \\
\text { (Sturge Weber Syndrome) } \\
\text { Cervical Neuroblastoma }\end{array}$ & $\begin{array}{l}5 \\
1 \\
1\end{array}$ \\
\hline $\begin{array}{l}\text { Congenital malformations of the circulatory } \\
\text { system }\end{array}$ & $5(3.13)$ \\
\hline $\begin{array}{l}\text { Hypoplastic left heart } \\
\text { Truncus Arteriosus } \\
\text { Hypertrophic cardiomyopathy } \\
\text { Gallen vein malformation } \\
\text { AV Septal defect }\end{array}$ & $\begin{array}{l}1 \\
1 \\
1 \\
1 \\
1\end{array}$ \\
\hline $\begin{array}{l}\text { Congenital malformations of the respiratory } \\
\text { system }\end{array}$ & $4(2.5)$ \\
\hline $\begin{array}{l}\text { Diaphragmatic hernia } \\
\text { Hypoplasic lung and thorax } \\
\text { Cystic adenomatoid malformation }\end{array}$ & $\begin{array}{l}1 \\
2 \\
1\end{array}$ \\
\hline Twin-related & $1(0.63)$ \\
\hline Conjoined Twins & 1 \\
\hline Miscellaneous malformations & $21(13.13)$ \\
\hline $\begin{array}{l}\text { Cystic hygroma of unknown etiology } \\
\text { Bilateral adrenal gland agenesis } \\
\text { Bilateral adrenal gland hyperplasia }\end{array}$ & $\begin{array}{r}13 \\
5 \\
3\end{array}$ \\
\hline
\end{tabular}




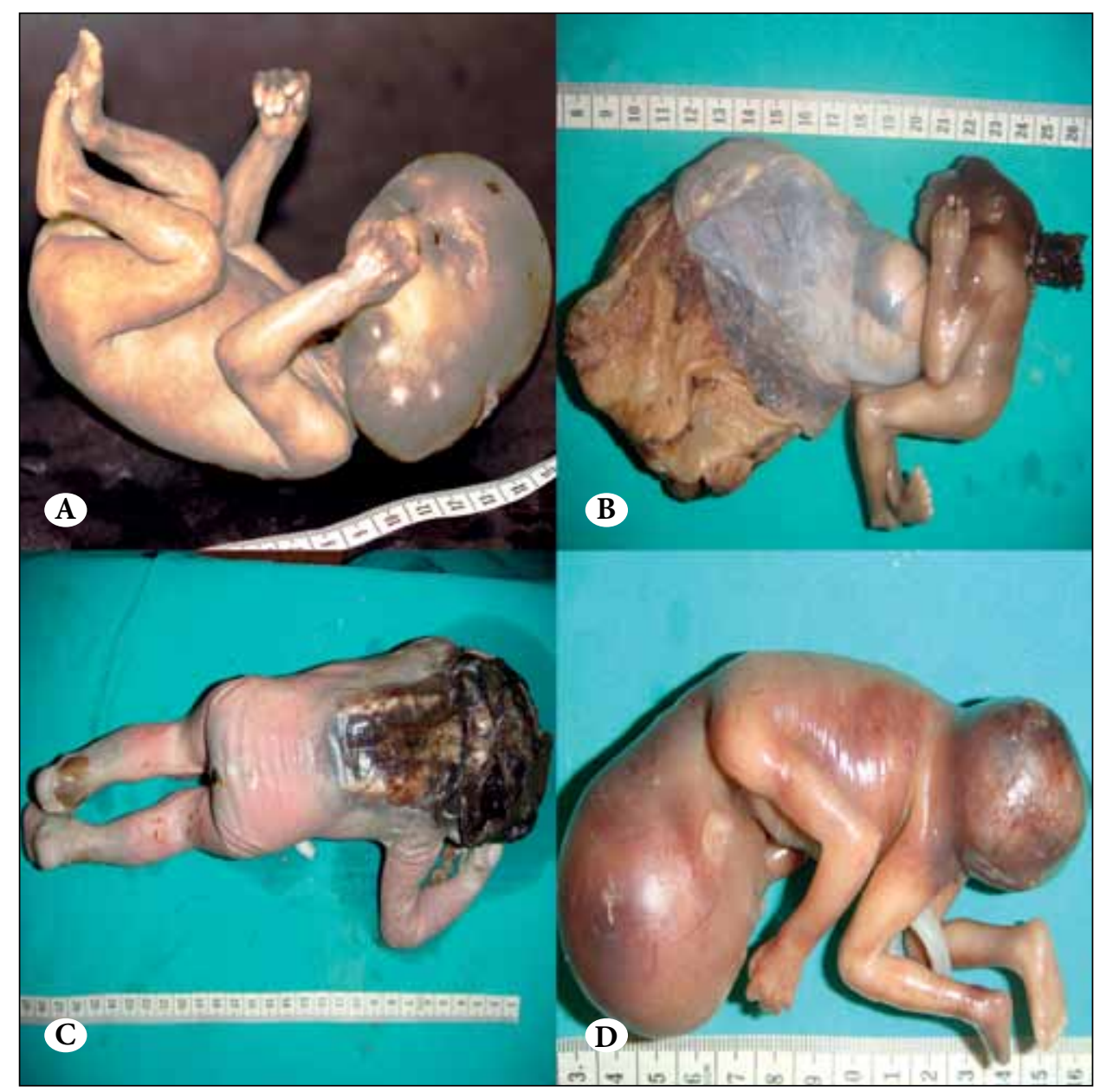

Figure 2: A) Congenital Cervical Neuroblastoma, B) Anencephaly and Gastroschisis, C) Anencephaly-Iniencephaly-Thoracal Rashisisis, D) Sacrococcygeal Teratoma.

kidney; however, the result of the autopsy showed no pathology in the kidney. One of them was diagnosed to have widespread calcification in the liver, and two of them only to have intrauterine growth retardation. The last case with cardiac anomaly was diagnosed on ultrasonographic examination, but there was no cardiac abnormality at autopsy. None of these four cases were terminated at the beginning, but died without reason. The reason of death could not be explained. The placenta was not examined.

Fetal autopsy provided additional findings in 43 cases (26.88\%), in 19 of which a revision of the diagnosis led to a significant change in the risk of recurrence in subsequent pregnancies (Table III).

\section{DISCUSSION}

The number of published studies on congenital anomalies in the Turkish population is limited. We found four studies from PubMed about neonatal congenital anomalies (1,68 ). There are also some studies on specific anomaly groups such as neural tube defect (9-11).
Informing and offering pregnancy termination in Turkey is not as difficult as it is in other Muslim countries. Laws give permission for pregnancy termination due to congenital anomalies, and families mostly approve the termination. However, in spite of legal freedom and personal tendency, 41 families rejected autopsy because of the social pressure on them and the psychological, cultural and religious notions they have $(1,3,12)$.

The annual birth rate in Turkey is 1.241.617 (5). We have not found any studies about the annual fetal anomaly rate. In our region, the annual average birth rate is 29.583 and we have found the annual fetal anomaly rate to be $0.10 \%$ (32 cases).

The autopsy rate in our study among the fetuses referred to us was $85 \%(233 / 274)$, while it was $79.9 \%$ in the Dickinson (13), $84 \%$ to $67 \%$ in the Boyd and all cases $(100 \%)$ in the Sankar study (2).

Central nervous system (CNS) disorders were the most frequent group of disorders in pregnancy losses, perinatal 
Table III: Additional anomaly findings through autopsy

\begin{tabular}{|l|c|c|}
\hline Type of anomaly & Number of cases & Recurrence risk (\%) \\
\hline Bilateral renal agenesis & 3 & 3 \\
\hline Unilateral renal agenesis & 3 & 25 \\
\hline Infantile policystic kidney disease & 4 & $3-4$ \\
\hline Bilateral multicystic renal displasia & 5 & - \\
\hline Cystic adenomatoid malformation & 1 & 25 \\
\hline Meckel Gruber Syndrome & 4 & - \\
\hline Facial Hemangioma (Sturge Weber Syndrome) & 1 & - \\
\hline Anal atresia & 1 & - \\
\hline Single umbilical artery & 9 & - \\
\hline Chorangiosis & 3 & - \\
\hline Cervical Neuroblastoma & 1 & - \\
\hline Bilateral adrenal agenesis & 5 & - \\
\hline Adrenal hyperplasia & 3 & \\
\hline
\end{tabular}

and postnatal mortalities and congenital anomalies, with a reported frequency of $20-45 \%$ (45.5\%, Pinar (14), 1998; 29.4\%, Ceylaner (10), 2007; 26.4\%, Nielsen (15), 2006; 34.8\%, Amini (4), 2006; and 21.75\%, EUROCAT (16), 2003). In our study, 79 of the 160 cases had CNS, with a rate of $48.75 \%$. The results we obtained were higher than those found in the studies of other investigators $(1,2,7,14)$. This difference might suggest that regional differences and consanguinity, a common practice in most of Turkey and particularly in our region, should be taken into account.

As in the other studies, fetal loss investigations included radiographs, chromosomal analysis, fetal autopsy and histopathology of the placenta $(17,18)$. Skeletal radiograph is an obligatory part of fetal autopsy protocol, particularly if skeletal dysplasia is suspected as in the case of short limbs. Although skeletal dysplasia might be reconsidered by ultrasound, only postmortem radiography can yield an accurate diagnosis $(19,20)$. This is significant as the risk of recurrence ranges from negligible to $25 \%$. In the series of Tunçbilek E et al., the most frequent congenital malformations were those in the musculoskeletal system (8). However, in our series, malformations of the musculoskeletal system were the second most frequent at a rate of 36/160 (22.5\%) cases as suspected by ultrasonography and confirmed by postmortem radiography.

As reported in some studies, chromosomal abnormalities are the most common findings in fetal abnormalities $(13,14)$. In our study, we only analyzed chromosomal anomalies in 45 cases due to various reasons. In our series, we also found the rate of chromosomal abnormalities to be high, accounting for 11 (24.44\%) of the 45 cases. Down's syndrome (8 cases) was the most common finding in this group $(72.72 \%)$.

Some series have focused on whether some anomalies identified in fetal fetuses were accompanied by other anomalies, and whether the rate of correlation between the different anomalies was significant. Nielsen LAet al. found well-known associations of CNS with specific morphological anomalies and specific organ weights, and also suggested an association between adrenal hypoplasia and cephalocele (15). We found a significant correlation between central nervous system malformations (78 cases) and adrenal agenesis (4 cases) with a rate of $5.13 \%$. Our findings are similar to those identified by Nielsen LA et al., which shows that the correlation between central system malformations and adrenal agenesis is a significant factor to be further investigated in other studies (15). However, Ceylaner $\mathrm{G}$ et al. found that the additional malformation was that occurring in the muscoloskeletal system (1). We have also found that the second most frequent correlation was between congenital malformations of the musculoskeletal system (36 cases) and renal pathology (renal agenesis, renal dysplasia) in 5 cases with a rate of $13.9 \%$.

Generally, prenatal ultrasound is expected to detect major fetal structural anomalies, and although detection rates may vary, the majority of severe fetal anomalies are recognized prenatally (21-23). Nonetheless, additional findings which may influence the risk of recurrence can be obtained with fetal autopsy. For example, if a fetus found to have a neural tube defect (recurrence risk 3-5\%) by ultrasonography yielded additional findings like polydactyly and renal malformation on fetal autopsy, the 
revised diagnosis would be Meckel syndrome, which has autosomal recessive inheritance with a recurrence risk of $25 \%$ in subsequent pregnancies. In this study, four cases of Meckel Gruber Syndrome, 4 cases of infantile (autosomal recessive) polycystic renal disease (recurrence risk of 25\%), 5 cases of cystic renal dysplasia and 6 cases of bilateral renal agenesis (recurrence risk of $3 \%$ ) had not been previously identified with ultrasonographic examination, but only diagnosed through the histopathological examination of fetal organs.

The additional finding rate as a result of fetal autopsy was $27 \%$ (35/132) in Boyd's study (3). In Dickinson's study (13), the risk alteration for subsequent pregnancies appeared to have changed by $49.4 \%$ in 45 cases, and Sankar VH and Phadke SR (2) obtained significant additional information about $38 \%$ of the cases and the recurrence risk change was $18 \%$ in his analysis of 138 fetuses in a 5-year period. Fetal autopsy provided additional findings in 43 cases in our study. The recurrence risk increased in 11 of the 43 $(25.58 \%)$ cases. This result was in accordance with the results of previous similar studies.

Consanguinity in a population is a very important factor regarding the appearance of congenital defects and recessively transmitted hereditary diseases. Several studies from different regions in Turkey have shown consanguinity rates to range from 11.7 to $35.2 \%$ (24). We only interviewed the parents of fetuses with anomalies about consanguinity, and we found a rate of $27.5 \%$ (44/160 cases). However, there has been no study on the rate of consanguinity in our region so far. We were therefore unable to compare our results. Studies are needed on this subject.

We employed MSCT in order to detect the depth of tumor invasion into bones and cerebral tissues in 1 congenital cervical neuroblastoma case (Figure 2). We also used the same method in skeletal dysplasia cases. We used MRI to see the depth of invasion of the tumour into soft tissues in sacrococcygeal teratoma cases. We believe that advanced imaging tools can yield better results with higher precision, and should be employed more frequently.

In summary, the quality of devices is continually increasing and yielding more accurate results with an ultrasound scan. However, the role of fetal autopsy remains very important in order to clearly identify some other defects in terminated fetuses. Parents can also be better informed about the possible risks in future pregnancies with the help of the findings received through fetal autopsy so that they can take necessary precautions. A larger number of cases is required for a more accurate evaluation.

\section{REFERENCES}

1. Ceylaner G, Ceylaner S, Günyeli I, Ekici E, Celasun B, Danışman $N$ : Evaluation of 2407 fetuses in a Turkish population. Prenat Diagn 2007, 27: 800-807

2. Sankar VH, Phadke SR: Clinical utility of fetal autopsy and comparison with prenatal ultrasound findings. J Perinatol 2006, 26: 224-229

3. Boyd PA, Tondi F, Hicks NR, Chamberlain PF: Autopsy after termination of pregnancy for fetal anomaly: retrospective cohort study. Br Med J 2004, 17:328:137

4. Amini H, Antonsson P, Papadogiannakis N, Ericson K, Pilo C, Eriksson L, Westgren M, Axelsson O: Comparison of ultrasound and autopsy findings in pregnancies terminated due to fetal anomalies. Acta Obstet Gynecol 2006, 85: 1208-1216

5. http://www.tuik.gov.tr/jsp/duyuru/upload/vt/vt.htm.

6. Say B, Tunçbilek E, Balci S, Muluk Z, Gögüs T, Saraçlar M, Koçal C: Incidence of congenital malformation in a sample of the Turkish population. Hum Hered 1973, 23: 434-441

7. Himmetoglu O, Tiraş MB, Gürsoy R, Karabacak O, Şahin I, Onan A: Incidence of congenital malformation in a Turkish population. Int J Gynaecol Obstet 1996, 55: 117-121

8. Tunçbilek E, Boduroğlu K, Alikasifoğlu M: Results of the Turkish congenital malformation survey. Turk J Pediatr 1999, 41:287-297

9. Mandıracıoğlu A, Ulman I, Luleci E, Ulman C: The incidence and risk factors of neural tube defects in İzmir, Turkey: a nested case control study. Turk J Pediatr 2004, 46: 214-220

10. Ceylaner S, Ceylaner G, Günyeli I, Ekici E, Tug M, Taner D, Ekerbicer H, Mollamahmutoğlu L, Danişman N: Postmortem evaluation of 220 prenataly diagnoses fetuses with neural tube defect detection of associated anomalies in a Turkish population. Prenat Diagn 2006, 26: 147-153

11. Onrat ST, Seyman H, Konuk M: Incidence of neural tube defects in Afyonkarahisar, Western Turkey. Genet Mol Res 2009, 8: 154-161

12. Sloan EP, Kirsh S, Mowbray M: Viewing the fetus following termination of pregnancy for fetal anomaly. JOGNN 2008, 37: 395-404

13. Dickinson JE, Prime DK, Charles AK: The role of autopsy following pregnancy termination for fetal abnormality. ANZJOG 2007, 47: 445-449

14. Pinar H, Tatevosyants N, Singer DB: Central nervous system malformations in a perinatal/neonatal autopsy series. Pediatr Dev Pathol 1998, 1:42-48

15. Nielsen LA, Maroun LL, Broholm H, Laursen H, Graem N: Neural tube defect and associated anomalies in a fetal perinatal autopsy series. APMIS 2006, 114:239-46

16. EUROCAT final report to Department of Health. A study of the Geographical Variation in Overall Rates of Congenital Abnormalities and the Rates of Specific Abnormalities. DH/ DETR/Environment Agency Joint Research Programme on the possible Health Effects of Landfill Sites. Project LSHTM/00/2, Agust 2003

17. Curry CJ: Pregnancy loss, stillbirth and neonatal death. A guide fort he Pediatrican. Medical genetics-I. Pediatr Clin North Am 1992, 39:36-52 
18. Oslen OE, Espeland A, Maartmann-Moe H, Lachnman RS, Rosendahl K: Diagnostic value of radiography in cases of perinatal death: a population based study. Arch Dis Child Fetal Neonatal Ed 2003, 88: F521-F524

19. Bourke J, Bower C, Blair E, Charles A, Knuiman M: Thre effect of termination of pregnancy for fetal abnormalites on trends in mortality to one year of age in Western Australia. Paediatr Perinat Epidemiol 2005, 19:284-293

20. Dighe M, Flinger C, Cheng E, Warren B, Dubinsky T: Fetal skeletal dysplasia: an approach to diagnosis with illustrative cases. Radiographics 2008, 28:1061-1077

21. Piercecchi-Marti MD, Liprandi A, Sigaudy S, Fredouille C, Adalian P, Figarella-Branger D, Pellissier JF: Value of fetal autopsy after medical termination of pregnancy. Forensic Sci Int 2004, 144:7-10
22. Grandjean H, Larroque D, Levi S: The performance of routine ultrasonographic screening of pregnancies in the Eurofetus study. Am J Obstet Gynaecol 1999, 181:446-454

23. Garne E, Loane M, Dolk H, De Vigan C, Scarano G, Tucker D, Stoll C, Gener B, Pierini A, Nelen V, Rösch C, Gillerot Y, Feijoo M, Tincheva R, Queisser-Luft A, Addor MC, Mosquera C, Gatt M, Barisic I: Prenatal diagnosis of severe structural congenital malformations in Europa. Ultrasound Obstet Gynaecol 2005, 25: 6-11

24. Özdemir H, Alper Z, Bilgel N: Consanguineous marriages in a suburb of a Metropolitan city: A study from Bursa, Turkey. Turkiye Klinikleri J Med Sci 2009, 29:1235-1241 